\title{
Chemically induced mutagenesis of diploid wheat Triticum sinskajae A. Filat. et Kurk.
}

Kuluev A.R., Zaikina E.A., Kuluev B.R., Chemeris A.V.

Institute of Biochemistry and Genetics - Subdivision of the Ufa Federal Research Centre of the Russian Academy of Sciences, Ufa, Russia

E-mail: kuluev.azat91@mail.ru

Key message. Mutagenesis of Triticum sinskajae was performed using sodium azide. The optimal concentration was 0.1 mM. Changes were observed in the length of the spike and stem in the experimental plants as compared with the control ones. Keywords: T. sinskajae, mutagenesis, sodium azide, selection, ISSR analysis.

The cultivation tradition of eincorn wheat is still preserved in many countries of the world, however, of these wheats only Triticum sinskajae A. Filat. et Kurk is easily threshed, but it is this diploid form that is not cultivated in the fields. It is characterized by rapid growth, early maturity and the highest protein content among diploid wheats. It is these qualities that make this type of wheat very attractive for domestication and cultivation. But along with this, T. sinskajae lacks genetic polymorphism. To overcome this barrier, chemically induced mutagenesis can be used. The aim of this study is to create mutant forms of $T$. sinskajae to increase its level of polymorphism. We performed chemically induced mutagenesis using sodium azide $\left(\mathrm{NaN}_{3}\right)$ at concentrations from $0.1 \mathrm{mM}$ to $0.6 \mathrm{mM}$. To evaluate the mutagenic and toxic effects of sodium azide, a morphometric analysis was carried out, consisting in measuring the height of the stem and the length of the spike. To evaluate the total mutagenic effect of sodium azide on $T$. sinskajae, we performed an ISSR analysis of plants exposed to the mutagen. When using a $0.1 \mathrm{mM}$ sodium azide concentration, more than half of all treated seeds emerged, whereas without treatment with mutagen (control in phosphate buffer), the seed germination of T. sinskajae approached 100\%. In general, among the experimental plants, a decrease in the growth rate and a slowdown in development were observed. The height of the stem of the experimental plants were lower than the control. According to the length of the spike, the experimental plants had a decrease compared with the untreated mutagen control. As a result of the ISSR analysis, there was a clear demarcation between experimental plants and other species and lines, which suggests that chemically induced mutagenesis can be assessed using ISSR analysis. Also, in all our studies, the cluster T. monococcum - T. boeoticum - T. sinskajae was determined, while T. urartu was always farther from these species. So, we obtained potentially mutant forms of $T$. sinskajae using by sodium azide. Further development in this direction is the improvement of economically useful signs of $T$. sinskajae for domestication.

\section{Химически индуцированный мутагенез диплоидной пшеницы Triticum sinskajae A. Filat. et Kurk.} Кулуев А.Р., Заикина Е.А., Кулуев Б.Р, Чемерис А.В.

Институт биохимии и генетики - обособленное структурное подразделение Федерального государственного бюджетного научного учреждения Уфимского федерального исследовательского центра Российской академии наук, Уфа, Россия

Был проведен мутагенез Triticum sinskajaе при помощзи азида натрия. Оптимальная концентрация составила 0.1 Мм. Наблюдались изменения в длине колоса и стебля у опьтных растений по сравнению с контрольными.

Ключевые слова: T. sinskajaе, мутагенез, азид натрия, селекиия, ISSR-анализ.

Традиции возделывания пшениц-однозернянок до сегодняшнего дня сохраняется во многих странах мира, однако из этих пшениц лишь Triticum sinskajae A. Filat. et Kurk. является легкообмолачиваемой, но именно эта диплоидная форма на полях не выращивается. Она характеризуется быстрым ростом, скороспелостью и наивысшим показателем содержания белка среди диплоидных пшениц. Именно эти качества делают данный вид пшениц весьма привлекательным для доместикации и окультуривания. Но вместе с этим у пшеницы Синской отсутствует генетический полиморфизм. Для преодоления этой преграды можно использовать химически индуцированный мутагенез. Целью данного исследования является создание мутантных форм пшеницы Синской для увеличения ее уровня полиморфизма. Мы проводили химически индуцированный мутагенез с помощью азида натрия (NaN 3 ) при концентрациях от 0,1 мМ до 0,6 мМ. Для оценки мутагенного и токсического эффектов азида натрия проводили морфометрический анализ, заключающийся в измерении высоты стебля, длины колоса. Чтобы оценить общий мутагенный эффект азида натрия на T. sinskajae, мы провели ISSR-анализ подвергнутых действию мутагена растений. При использовании концентрации азида натрия 0,1 мМ всходила более половины всех обработанных семян, тогда как без обработки мутагеном (контроль в фосфатном буфере) всхожесть семян пшеницы Синской приближалась к $100 \%$. В целом, среди опытных растений наблюдалось уменьшение скорости роста и замедление развития. По высоте стебля опытные растения оказались ниже контрольных. По длине колоса, у опытных растений было уменьшение по сравнению с необработанным мутагеном контролем. В результате ISSR-анализа было четкое разграничение опытных образцов от остальных видов и линий, что говорит о том, что проведенный химически индуцированный мутагенез можно оценивать с помощью ISSR-анализа. Также во всех наших исследованиях определялся кластер T. топососсит - T. boeoticum - T. sinskajae, в то время как T. urartu всегда был дальше от этих видов. Итак, нами при помощи азида натрия были получены потенциально мутантные формы T. sinskajae. Дальнейшее развитие в этом направлении - это улучшение хозяйственно-полезных признаков $T$. sinskajae для доместикации. 